\title{
A Carbon Tax for a Brighter Future
}

\author{
Alberto Majocchi and Antonio Padoa-Schioppa
}

Emmanuel Macron's victory has opened unexpected prospects for the European Union. These were made plain by an impressive number of innovative proposals given in his speech at the Sorbonne University on September $27^{\text {th }}, 2018$. Also the myth (because this is what it is, after all) of national sovereignty's intangibility was specifically disproved: on the contrary, there is to win back at the European level a sovereignty that the European States, without exception, have by now lost at the national level.

Inter alia, the most strategically outstanding proposition of the French President was in our opinion the one to introduce shortly a European tax on carbon dioxide emissions (the so-called carbon tax). This is not a new idea, though it seems that only now has it become weighty enough to reach the stage of its concrete implementation.

This proposal is relevant for several reasons. First of all, it pursues the aim to effectively fight the dramatic increase of environmental deterioration caused by climate change and directly imputable to man's action, which is threatening the entire Planet. Emissions of $\mathrm{CO}_{2}$ are a significant part of this threat.

Secondly, the carbon tax revenues could fund development policies which are fundamental for the European Union not only for countercyclical purposes, but also in order to fulfill the objectives included in the Treaties through investments in European public goods, essential to the future of our Continent. They comprise, beside the protection of the environment and the territory, the funding of basic research; a common policy for energy and the development of renewable resources; large investments in computer science and artificial intelligence, which cannot beignored by the EU and be left under the US'and China's leadership; a comprehensive valorization of our cultural patrimony, and much more.

In fact, the amount of resources coming from a carbon tax would lead to an impressive increase in the European Union's budget. It has been reckoned that by applying the rates proposed by Macron in his speech (25 to 30 Euro per ton of $\mathrm{CO}_{2}$ ) to the domestic sector, transport, agriculture and small and mediumsized businesses - i.e. the sectors excluded from the Emission Trading Scheme (ETS) -, the revenue could potentially reach 55-65 billion euro. However, if the rate will gradually grow to 50 Euro, as suggested by climate change experts, the yield in the 27-country EU would reach 110 billion euro, with an impact of about 11 cents per liter of petrol. This would in practice lead to a doubling of the EU budget, which is stuck today at $1 \%$ of the European GDP, completely inadequate to fund the new policies that Europe imperatively needs.

In his speech at the Sorbonne University, Macron has also highlighted the fact that the introduction of the carbon tax must be accompanied by the imposition of a border tax - equivalent to the one paid by European companies - in order to eschew any distortion of a fiscal nature and consequently a loss of competitiveness for the European firms, or even the delocalization of European products 
to those countries that do not apply a price for carbon emissions (the so-called "carbon leakage"). Instead, a border tax would bring an additional 25 billion euro, approximately, to the EUbudget, to which the revenue of the auctions for the negotiable permits purchase within the ETS should be added in the nearfuture.

Obviously, a significant increase in the resources of the EU budget raises the issue of ensuring proper democratic procedures in fiscal and taxation matters. This applies not only to the amount and regulation of the carbon tax, but also to the use of the resources that would be made available. A coherent choice is to grant on both issues an adequate role to the European Parliament, in codecision with the Council. For what concerns the management, the best procedure would be to assign it to the Commission, conferring the task to a Commissioner Minister of Economy, here again under the control of the Parliament and the Council. At that stage, it would be appropriate for the tax revenue to be in all respects included in the European Union's budget.

An alternative possibility would be to create an Agency, institutionally controlled by the Union, empowered with the management of the carbon tax resources, following a model which has been tested in the past in the ECSC and in the Euratom, which, it is worth noting, is still in force.

These are delicate problems, but they can be overcome with political goodwill, especially on the part of France and Germany. Even Italy, if its internal policies were reliable, could havea say in the matter. 